\title{
LITTER FALL PRODUCTION AND DECOMPOSITION IN A FRAGMENT OF SECONDARY ATLANTIC FOREST OF SÃO PAULO, SP, SOUTHEASTERN BRAZIL ${ }^{1}$
}

\author{
Maurício Lamano Ferreira², Jaqueline Luana Silva ${ }^{3}$, Edna Elisa Pereira ${ }^{4}$ e Ana Paula do Nascimento \\ Lamano-Ferreira $^{5}$
}

\begin{abstract}
RESUMO - Litter fall consists of all organic material deposited on the forest floor, being of extremely important for the structure and maintenance of the ecosystem through nutrient cycling. This study aimed to evaluate the production and decomposition of litter fall in a secondary Atlantic forest fragment of secondary Atlantic Forest, at the Guarapiranga Ecological Park, in São Paulo, SP. The litter samples were taken monthly from May 2012 to May 2013. To assess the contribution of litter fall forty collectors were installed randomly within an area of 0.5 ha. The collected material was sent to the laboratory to be dried at $65{ }^{\circ} \mathrm{C}$ for 72 hours, being subsequently separated into fractions of leaves, twigs, reproductive parts and miscellaneous, and weighed to obtain the dry biomass. Litterbags were placed and tied close to the collectors to estimate the decomposition rate in order to evaluate the loss of dry biomass at 30, 60, 90, 120 and 150 days. After collection, the material was sent to the laboratory to be dried and weighed again. Total litter fall throughout the year reached 5.7 Mg.ha-1.yr-1 and the major amount of the material was collected from September till March. Leaves had the major contribution for total litter fall (72\%), followed by twigs (14\%), reproductive parts (11\%) and miscellaneous (3\%). Reproductive parts had a peak during the wet season. Positive correlation was observed between total litter and precipitation, temperature and radiation $(r=0.66, p<0.05 ; r=0.76, p<0.05 ; r=$ $0.58, \mathrm{p}<0.05$, respectively). The multiple regression showed that precipitation and radiation contributed significantly to litter fall production. Decomposition rate was in the interval expected for secondary tropical forest and was correlated to rainfall. It was concluded that this fragment of secondary forest showed a seasonality effect driven mainly by precipitation and radiation, both important components of foliage renewal for the plant community and that decomposition was in an intermediate rate.
\end{abstract}

Keywords: Urban forest; Nutrient cycling; Guarapiranga Ecological Park.

\section{PRODUÇÃO E DECOMPOSIÇÃO DE SERAPILHEIRA NUM FRAGMENTO DE FLORESTA SECUNDÁRIA ATLÂNTICA DE SÃO PAULO, SUDESTE DO BRASIL}

\begin{abstract}
RESUMO - A serapilheira consiste de todo o material orgânico depositado no chão da floresta, sendo de extrema importância para a estrutura e manutenção do ecossistema através da ciclagem de nutrientes. Este estudo teve como objetivo avaliar a produção e decomposição de serapilheira em um fragmento de Mata Atlântica secundária no Parque Ecológico do Guarapiranga, em São Paulo, SP. As coletas de serapilheira foram realizadas mensalmente a partir de maio de 2012 até maio de 2013. Para avaliar a contribuição da serapilheira, 40 coletores foram instalados aleatoriamente dentro de uma área de 0,5 ha. O material recolhido foi enviado a laboratório para ser seco a $65^{\circ} \mathrm{C}$ durante $72 \mathrm{~h}$, sendo posteriormente separado em frações de folhas, galhos, partes reprodutivas e miscelânea, pesadas para obter a biomassa seca. Litterbags foram colocados e amarrados perto dos colectores, para estimar a taxa de decomposição, a fim de avaliar a perda de biomassa seca em 30, 60, 90, 120 e 150 dias. Após a coleta, o material foi enviado a laboratório
\end{abstract}

\footnotetext{
${ }^{1}$ Recebido em 03.10.2013 aceito para publicação em 04.05.2014.

${ }^{2}$ Universidade Nove de Julho, UNINOVE, Brasil. E-mail: <mauecologia@yahoo.com.br>.

${ }^{3}$ Graduanda em Ciências Biológicas, Universidade Nove de Julho, UNINOVE, Brasil. E-mail: <jaquelinesabbath@hotmail.com>.

${ }^{4}$ Graduada em Ciências Biológicas, Universidade Nove de Julho, UNINOVE, Brasil. E-mail: < Edna.Pereira@syngenta.com>.

${ }^{5}$ Universidade Nove de Julho, UNINOVE, Brasil. E-mail: <apbnasci@yahoo.com.br>.
} 


\begin{abstract}
para ser seco e pesado novamente. A serapilheira total alcançou ao longo do ano 5,7 Mg.ha-1, em que se observou a maior quantidade de material no período de setembro a março. As folhas tiveram a maior contribuição para a serapilheira total (72\%), seguidas de galhos (14\%), partes reprodutivas (11\%) e miscelânea (3\%). As partes reprodutivas tiveram um pico durante a estação chuvosa. Verificou-se correlação positiva entre serapilheira total e precipitação, temperatura e radiação $(r=0,66, p<0,05, r=0,76, p<0,05, r=$ $0,58, p<0,05$, respectivamente). A regressão múltipla mostrou que a precipitação e radiação contribuíram significativamente para a produção de serapilheira. A taxa de decomposição se manteve dentro do intervalo esperado para florestas tropicais secundárias e foi correlacionada com precipitação. Conclui-se que esse fragmento de floresta secundária mostrou efeito da sazonalidade impulsionado, principalmente, pela precipitação e radiação, os dois componentes importantes para a renovação do folhedo pela comunidade vegetal; $e$, também, que a decomposição estava em taxa intermédia.
\end{abstract}

Palavras-chave: Floresta urbana; Ciclagem de nutrientes; Parque Ecológico do Guarapiranga.

\section{INTRODUCTION}

The Atlantic Forest is one of the richest ecosystems in biodiversity worldwide and it is considered a hot spot. This forest extends along the Brazilian coast and suffers from a continuing devastation due to anthropogenic factors such as logging and agriculture (SOS ATLANTIC, 2013). Another important reason in this devastation is the land use change for residential purposes and tourism, functioning as an escape valve to shelter the surplus population. According to Yong (2005) the Atlantic Forest houses two-thirds of the Brazilian population. Currently there are only fragments of different sizes in the Atlantic Forest presenting a great floristic variation due to climatic variations (LEITÃO FILHO, 1987). The transformation of vast areas of primary forests causes increase areas of secondary forests, which should be monitored in the context of conservation and public policy.

The monitoring of litter fall dynamics has been one of the most used methods for the evaluation of forest productivity (OLIVEIRA, 1999) by representing one of the main pathway for nutrients transfer to the soil (VITAL et al., 2004). Litter fall is a large transitional nutrients bank that may interfere with the species composition, structure and dynamics of communities, and plays a key role in the transfer of energy between trophic levels (FACELLI; PICKETT, 1991; SAMPAIO et al., 2003). It is possible to find a greater contribution of litter fall in forest ecosystems in the early stages of succession, a fact that decreases as the community reaches later stages (VIBRANS; SEVEGNANI, 2000; DICKOW et al., 2012).

The production of this material, predominantly vegetable, can be influenced by biotic and abiotic factors such as vegetation type, temperature, precipitation, altitude, latitude, successional stage, light, soil characteristics, water availability among others (FIGUEIREDO FILHO et al., 2003). Tropical forests have a great variety of flora and consequently a very diverse community of decomposers organisms (SANCHES et al., 2009). As for primary forests, the dynamics of secondary forests depends on the nutrient cycling in the ecosystem. These forests usually have poor soil (POGGIANI, 1982), supporting the plant community through the process of decomposing organic matter and returning the elements to the root systems. According to Ostertag et al. (2008) secondary forest are a dominant lad-cover type in the tropics, but there are fewer studies on its functioning, and even less investigations in forests greater than 20 years. Thus, it is crucial to understand the dynamics of forest ecosystems, especially secondary forests, once there is a currently discussion about reforestation policy in disturbed and abandoned areas. Thus, the present study aimed to evaluate the production and decomposition of litter fall at the Guarapiranga Ecological Park, a secondary Atlantic Forest fragment, located in São Paulo, SP.

\section{MATERIALAND METHODS}

\subsection{Study area}

The study was conducted in the Ecological Park of Guarapiranga, just on the left margin of Guarapiranga

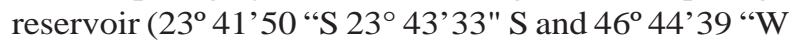
to $46^{\circ} 47^{\prime} 09^{\prime} \mathrm{W}$ ), a fragment of secondary Atlantic forest, located in São Paulo, SP, Brazil. The park is $730 \mathrm{~m}$ above sea level. The Guarapiranga Basin is influenced by two types of climate: type Cwb - warm temperate climate with rainy summer; and Cfb - constantly moist warm temperate climate, according to Köppen classification. Annual rainfall ranges from 1,300 to 1,900 
$\mathrm{mm}$, with prevalent rainfall in the summer months and predominantly dry winter. Average temperatures ranges from 16 to $23^{\circ} \mathrm{C}$ and prevailing winds are from SW to NE (SETZER, 1946 apud LIBERG, 2003).

\subsection{Litter production and decomposition}

Forty litter traps were installed and distributed randomly approximately $0.5 \mathrm{~m}$ above the ground into an area of $50 \mathrm{~m} \times 100 \mathrm{~m}$. The samples were taken monthly from the traps and dried in an oven at $65^{\circ} \mathrm{C}$ for 72 hours, until a constant weight was reached. Afterwards, the material was separated into fractions of leaves, twigs, reproductive parts and miscellaneous and weighed on an analytical digital scale with precision of three decimal points to obtain the dry mass. Litter production was estimated according to Lopes et al., 2002, based on the following equation:

$$
\mathrm{ALP}=(\Sigma \mathrm{MP} * 10,000) / \mathrm{CA}
$$

in which ALP = annual average of litter fall production $\left(\mathrm{kg} \cdot \mathrm{ha}^{-1} \cdot \mathrm{yr}^{-1}\right), \mathrm{MP}=$ monthly average of litter fall production $\left(\mathrm{kg} \cdot \mathrm{ha}^{-1} \cdot \mathrm{yr}^{-1}\right), \mathrm{CA}=$ collector area $\left(\mathrm{m}^{2}\right)$.

Four decomposition litterbags of polyvinyl were used with dimensions of 25 x 25 x $1.5 \mathrm{~cm}$. Ten grams of the dried material deposited in the traps were placed into litterbags. Thirty bags were randomly distributed in the forest floor and five litterbags were monthly collected to evaluate the decomposition rate following a time interval of 30, 60, 90, 120 and 150 days. The samples were taken to the laboratory again and dried at $65^{\circ} \mathrm{C}$ for 72 hours until a constant weight was reached, and then weighed on an accurate analytical scale. The decomposition rate was obtained at the end of the experiment from the mass loss, using the following model: $\mathrm{x} 100$

Remaining mass $(\%)=($ final mass $/$ initial mass $)$

Afterwards, the decomposition constant (K) was calculated according to Pereira et al. (2008), with the exponential model:

$$
\mathrm{Xt}=\mathrm{Xo} \cdot \mathrm{e}^{-\mathrm{kt}} \text {, }
$$

in which $\mathrm{Xt}=$ dry weight of the remaining material after $\mathrm{t}$ days; $\mathrm{Xo}=$ dry weight of the material placed in the litterbags at time zero $(\mathrm{t}=0)$.

The half-life time $\left(\mathrm{t}_{0,5}\right)$ was calculated according to Rezende et al. (1999), as follows:

$$
\mathrm{T}_{0,5}=\ln (2) / \mathrm{K}
$$

and the time of $95 \%$ of the material decomposition was obtained by the model:

$$
\mathrm{T}_{0,05}=3 / \mathrm{K}
$$

in which $\mathrm{K}$ is the decomposition constant obtained by the model above.

\subsection{Statistical Analysis}

Initially, Pearson correlation analysis was performed with the objective of selecting which meteorological factors (precipitation, radiation, relative humidity, temperature and wind speed) probably influenced the responses of litter fall production. Afterwards, we performed multivariate regression analysis to determine how much of the variation in litter fall production (dependent variable) could be explained by abiotic factors (independent variables: temperature, relative humidity, global radiation, wind speed, precipitation), and which of them significantly contributed to explain such responses in the production of the material. These multivariate analyses were performed by stepwise method (step by step), in which the adjustment procedure for each regression began with a saturated model with all variables present, removing those from lower participation to explain the variations in litter fall production. At the end, only the variables that contributed significantly to explain the variations in biological variable remained.

Linear regression analyses were performed to establish a relationship between decomposition and precipitation using the statistical package Sigma Stat for Windows. To evaluate the variation in biomass loss during decomposition significant differences were sought at each sampling month. Therefore, we applied the analysis of variance with one factor. Whenever necessary analyses of variance (one way) were followed by a multiple comparison test (Student-Newman Keuls).

\section{RESULTS}

Some abiotic factors showed variation throughout the year. Rainfall was highest in the summer months, as an expected pattern for the region, however, June showed an atypical rainfall value for the season, which is considered dry period. The temperature also followed the typical trend for the region with higher values during the summer, but it was observed that the minimum temperature reached a high value in July, featuring some hot days in the month (Figure 1).

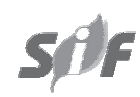

Revista Árvore, Viçosa-MG, v.38, n.4, p.591-600, 2014 
$\square$ Global radiation W.m-2.s-1 *-Temperature $\left({ }^{\circ} \mathrm{C}\right)$

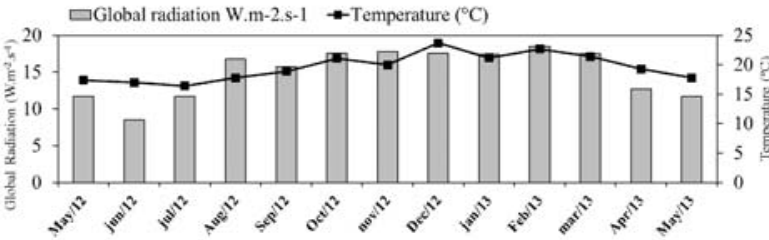

Figure 1 - Mean values of global radiation $\left(\mathrm{W} \cdot \mathrm{m}^{-2} \cdot \mathrm{s}^{-1}\right)$ and temperature $\left({ }^{\circ} \mathrm{C}\right)$ during the study period.

Figura 1 - Valores médios de radiação global (W.m-2.s-1) e temperatura $\left({ }^{\circ} \mathrm{C}\right)$ durante o período de estudo.

Solar radiation remained high from August to March. On average, the relative humidity and wind speed did not alter very much throughout the year.

Litter fall showed a strong seasonal pattern throughout the year and had an annual production

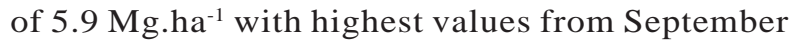
to March (wet season). Among these months, January had the lowest litter fall production. During April to August (dry season) lower values were found, reaching the highest value in April, with $376.2 \mathrm{~kg} \cdot \mathrm{ha}^{-1}$, and the lowest production in August, with $259.7 \mathrm{~kg} \mathrm{ha}^{-1}$ (Figure 2). January showed the lowest value of the wet season, which decreased concomitantly with rainfall.

A greater monthly and total participation of leaves was observed in the distribution of litter fall fractions (Figure 3AB), followed by twigs, reproductive parts and miscellaneous. Leaves, twigs and reproductive parts stood out with greater production from October to January, precisely the time of transition between spring and summer. Miscellaneous did not have a standard in its production throughout the year. Leaves were the main fraction produced in the litter fall.

Pearson correlation analysis indicated that the variations of litter fall production were stimulated by meteorological factors such as rainfall, temperature

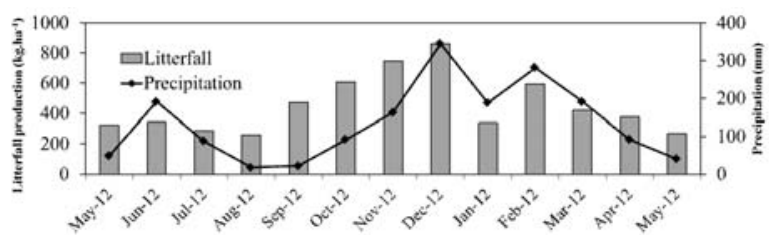

Figure 2 - Annual trend of litter fall production and rainfall during the study period. Measurements were taken from May 2012 to May 2013. Units are in kg.ha- ${ }^{-1}$

Figura 2 - Tendência anual da produção de serapilheira e precipitação durante o período de estudo. As medidas foram feitas de maio de 2012 a maio de 2013. As unidades estão em $\mathrm{kg} \cdot \mathrm{ha}^{-1}$. and solar radiation. The correlation matrices show that to leaves fraction, temperature, maximum temperature and solar radiation showed a strong positive influence in its fall. Regarding the twigs, rainfall seems to be the most important factor involved in its production in the collectors. The fall of reproductive parts was also influenced by precipitation and temperature. Finally the miscellaneous fraction was negatively influenced by temperature (Table 1 ). The relative humidity and wind speed does not seem to have influenced the plant material fall.

Finally, a multivariate analysis was carried out in which the litter fall production was the dependent variable. In this analysis, a saturated model with meteorological data (independent variables: temperature, relative humidity, rainfall, wind speed and solar radiation) was done. The result of this test was highly significant ( $\mathrm{p}=0.008)$ and indicated that litter fall production was explained by two inserted variables. The litter production increased as the precipitation $\left(\mathrm{p}=0.049, \mathrm{r}^{2}=0.55\right)$, and solar radiation $\left(\mathrm{p}=0.020, \mathrm{r}^{2}=0.44\right)$ increased.

Litter fall Production $=73,135+(1,046 *$ Precipitation $)+(0,541 *$ Radiation $)$

The equation that describes the decomposition rate of litter fall at this secondary forest is the mathematical model $y=-0.1188 x+2.4236$ with regression index of 0.95 , showing significance to $1 \%$, with values of biomass loss transformed into Log. The decomposition rate constant $(\mathrm{K})$, the time to decompose $50 \%\left(\mathrm{t}_{0.5}\right)$ and $95 \%\left(\mathrm{t}_{0.05}\right)$ of litter were, respectively, $0.0027,248$ days and 2.93 years. At the end of the experiment, $39.5 \%$ of the plant material placed in litterbags was decomposed. Figure 4A shows that after 30 days of the material exposure, the remaining mass was significantly lower than in the first day, showing a large loss due to decomposition. This trend stabilized after 120 days of the material exposure on the forest floor.

The decomposition of litter presented a strong correlation with rainfall throughout the study. Figure $4 \mathrm{~B}$ shows a positive linear correlation $\left(\mathrm{R}^{2}=0.76, \mathrm{p}\right.$ $=0.023$ ) which indicates that the greater amount of water might have influenced the increased microbial activity and decomposition rate. Figure 4C shows the ratio of biomass loss curve with precipitation. 


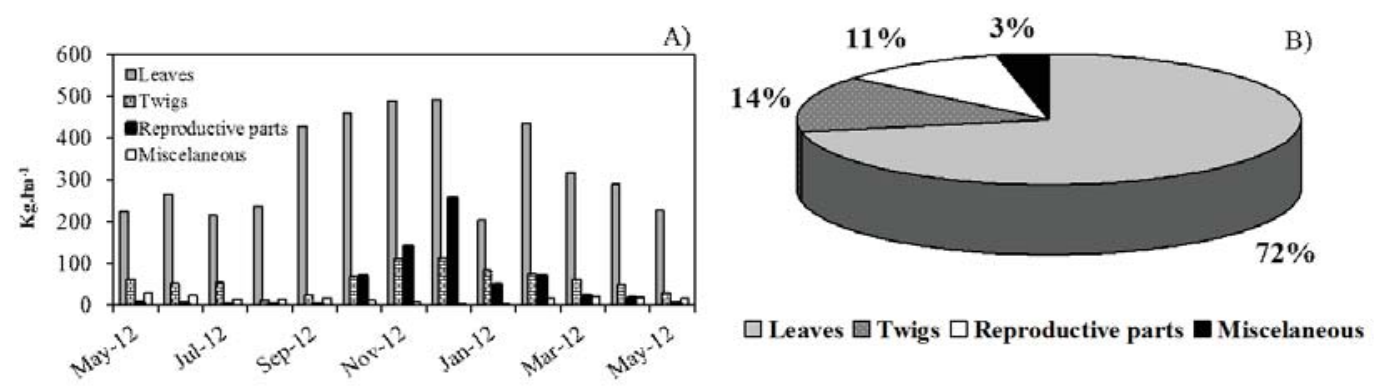

Figure 3 - Annual trend of litter fall fractions (leaves, stem, reproductive parts and miscellaneous). A) Bars representing the litter fall fractions in kg.ha-1 at the Guarapiranga Ecological Park. B) Mean annual percentage of litter fall fractions.

Figura 3 - Tendência anual das frações de serapilheira (folhas, caules, partes reprodutivas e miscelânea). A) As barras representam as frações de serapilheira em $\mathrm{kg} \mathrm{ha}^{-1}$ no Parque Ecológico do Guarapiranga. B) Porcentagem média anual das frações de serapilheira.

Table 1 - Pearson correlation coefficients (r) between means of litter fall and its fractions and meteorological factors (P - precipitation mm, T - temperature ${ }^{\circ} \mathrm{C}$, Tmax - Maximum temperature ${ }^{\circ} \mathrm{C}$, Tmin - minimum temperature ${ }^{\circ} \mathrm{C}, \mathrm{RH}$ - relative humidity \%, RHmax - maximum relative humidity, RHmin - Minimum relative humidity, R solar radiation $\mathrm{MJ} / \mathrm{m}^{2}$, WS - wind speed $\mathrm{m} / \mathrm{s}$ and WSmax - maximum wind speed $\mathrm{m} / \mathrm{s}$ ) throughout thirteen months of the study carried out between 2012 and 2013.

Tabela 1 - Coeficientes de correlação de Pearson (r) entre as médias de serapilheira total, suas frações e os fatores meteorológicos ( $P$ - precipitação $\mathrm{mm}, \mathrm{T}$ - temperatura ${ }^{\circ} \mathrm{C}$, Tmax - Temperatura máxima ${ }^{\circ} \mathrm{C}$, Tmin - temperatura mínima ${ }^{\circ} \mathrm{C}$, $R H$ - umidade relativa do ar \%, RHmax - umidade relativa do ar máxima, Rhmin - umidade relativa do ar mínima, $R$ - radiação solar $M J / m^{2}$, WS - velocidade de vento $\mathrm{m} / \mathrm{s}$ e WSmax - velocidade de vento máxima $\mathrm{m} / \mathrm{s}$ ) durante 13 meses de estudo realizado entre 2012 e 2013.

\begin{tabular}{lccccccccccc}
\hline & & $\mathrm{P}$ & $\mathrm{T}$ & $\mathrm{T} \max$ & $\mathrm{T} \min$ & $\mathrm{RH}$ & $\mathrm{RH} \max$ & $\mathrm{RH} \min$ & $\mathrm{R}$ & WS & WS Max \\
\hline Total litter fall & $\mathrm{r}$ & $0,66^{*}$ & $0,76^{*}$ & $0,67^{*}$ & 0,31 & 0,01 & 0,16 & $-0,04$ & $0,58^{*}$ & 0,29 & $-0,06$ \\
& $\mathrm{P}$ & $0,01^{*}$ & $0,00^{*}$ & $0,01^{*}$ & 0,30 & 0,98 & 0,61 & 0,90 & $0,04^{*}$ & 0,34 & 0,86 \\
Leaves & $\mathrm{r}$ & 0,45 & $0,67^{*}$ & $0,69^{*}$ & 0,16 & $-0,21$ & $-0,02$ & $-0,25$ & $0,62^{*}$ & 0,17 & 0,17 \\
& $\mathrm{P}$ & 0,12 & $0,01^{*}$ & $0,01^{*}$ & 0,60 & 0,50 & 0,95 & 0,42 & $0,02^{*}$ & 0,57 & 0,57 \\
\multirow{3}{*}{ Stem } & $\mathrm{r}$ & $0,77^{*}$ & $0,64^{*}$ & 0,35 & $0,51^{*}$ & 0,50 & 0,53 & 0,46 & 0,25 & $-0,38$ & $-0,38$ \\
& $\mathrm{P}$ & $0,00^{*}$ & $0,02^{*}$ & 0,24 & $0,07 *$ & 0,08 & 0,06 & 0,12 & 0,41 & 0,21 & 0,21 \\
\multirow{2}{*}{ Miscelaneouctive parts } & $\mathrm{r}$ & $0,73^{*}$ & $0,73^{*}$ & $0,58^{*}$ & 0,39 & 0,12 & 0,21 & 0,09 & 0,49 & 0,18 & $-0,31$ \\
& $\mathrm{P}$ & $0,00^{*}$ & $0,00^{*}$ & $0,04^{*}$ & 0,19 & 0,69 & 0,49 & 0,78 & 0,09 & 0,56 & 0,30 \\
& $\mathrm{r}$ & $-0,39$ & $-0,53^{*}$ & $-0,39$ & $-0,43$ & 0,11 & 0,12 & 0,11 & $-0,36$ & $-0,24$ & $0,49^{*}$ \\
& $\mathrm{P}$ & 0,18 & $0,06^{*}$ & 0,19 & 0,14 & 0,71 & 0,71 & 0,73 & 0,23 & 0,42 & $0,09 *$ \\
\hline
\end{tabular}

*Significant coefficient $(\mathrm{p}<0,05)$.

*Coeficiente significante $(p<0,05)$.

\section{DISCUSSION}

In general, the weather during this study showed an expected pattern for the region, with the exceptions of higher values of precipitation and temperature in June, which are not expected during the winter. A subtle lower amount of rainfall in January, which is one of the months with the highest rainfall level throughout the year.

Wet season showed higher production of litter fall with monthly values in the average of some works in tropical regions. Chave et al. (2010) found an average of 8.61 $\pm 1.91 \mathrm{Mg} \cdot \mathrm{ha}^{-1} \cdot \mathrm{yr}^{-1}$ for a pattern in South America, with values ranging from 5.19 - 12.47 Mg.ha ${ }^{-1} \cdot \mathrm{yr}^{-1}$. Dent et al. (2006) found a total fine litter fall production of $5.7 \mathrm{Mg} \cdot \mathrm{ha}^{-1} \cdot \mathrm{yr}^{-1}$ over 2 years study in an alluvial forest in Malaysia. Barlow et al. (2007) found 13.4 Mg.ha-1 $\mathrm{yr}^{-1}$ for a secondary forest in a degraded and abandoned area in Amazon. The authors commented that this high value might have reflected an effective restoring ecosystem processes. According to Kuruppuarachchi and Seneviratne (2013) higher litter fall helps to increase soil organic matter, thus contributing to increased nutrient release and aboveground biomass increment. The annual value of litter production found in this study is expected

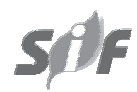

Revista Árvore, Viçosa-MG, v.38, n.4, p.591-600, 2014 
for secondary tropical forests and is in accordance with other authors (TOLEDO; PEREIRA, 2004; FERNANDES et al., 2006; VIDAL et al., 2007). A trend was observed towards higher production of the deciduous material beginning at the end of the dry season and ending up at the end of the rainy season. This trend has been observed in other studies in tropical forests. Werneck et al. (2001) observed higher litter fall production at the end of the dry season in a forest with different degrees of disturbance in Ouro Preto, MG, Brazil. On the other hand, some authors have observed in the Amazon region greater litter fall production at the end of rainy season (MALHADO et al., 2009; SILVA et al., 2009). Chave et al. (2010) found a positive correlation

\section{A)}

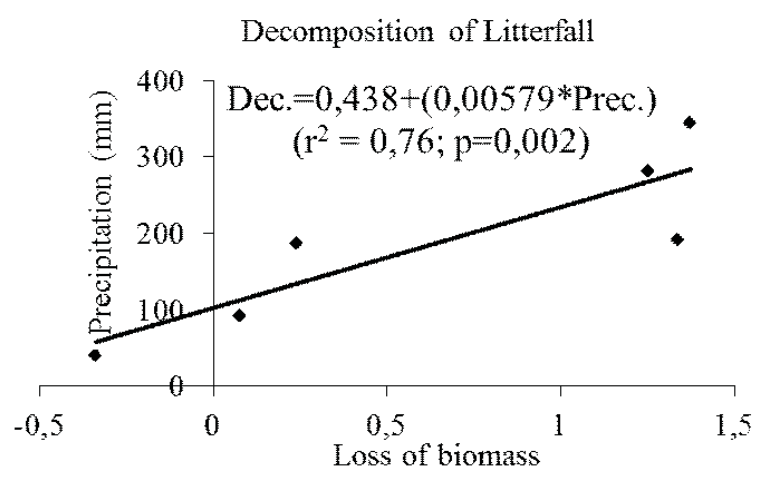

for litter fall and precipitation in a study in different plots in South America. Barlon et al. (2007) found a negative correlation between rainfall and litter production in a primary and secondary forest in Amazon.

The litter curve observed in this study shows a possible trend of the plant community to renew tree foliage for the following rainy season. It is noteworthy that from September on, important variables to the photosynthetic process such as precipitation, solar radiation and mean temperatures increase in the region. Another factor is that the forest is in the city of São Paulo, specifically near some intensive vehicular traffic routes, where it is expected to find a higher tropospheric

B)

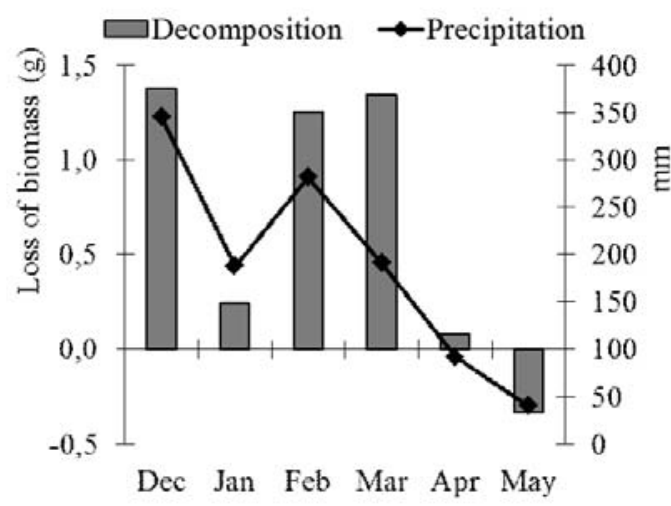

C)

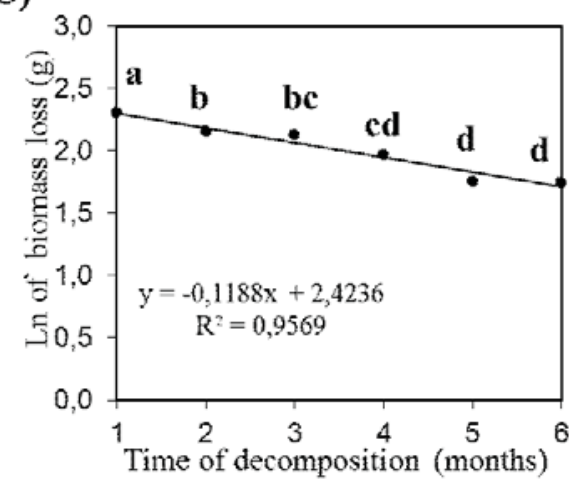

Figure 4 - Decomposition curves of litter fall at the Guarapiranga Ecological Park, SP. A) Values of biomass loss were transformed to logarithm. B) Loss of biomass and rainfall correlation during the exposure of litterbags (150 days). C) Curve of biomass loss and rainfall through decomposition experiment (grey bars mean the loss of biomass and the black line means the precipitation curve).

Figura 4 - Curvas de decomposição de serapilheira no Parque Ecológico do Guarapiranga, SP. A) Os valores de perda de biomassa foram transformados em logaritmo. B) Correlação entre perda de biomassa e regime de chuvas durante a exposição dos sacos de decomposição (150 dias). C) Curva de perda de biomassa e precipitação através de experimento de decomposição (barras cinzas significam a perda de biomassa, e a linha preta significa a curva de precipitação).

Revista Árvore, Viçosa-MG, v.38, n.4, p.591-600, 2014 
ozone formation, especially during the summer, when days have longer light period (FERREIRA et al., 2012). This phytotoxic pollutant may cause oxidative stress in the plants (FERREIRA; DOMINGOS, 2012; APRO et al., 2012) and changes in the mineral elements flux (MAYER, 1983), which can be responsible for the foliage fall. Liu et al. (2005), in a FACE study, found higher litter production in an elevated $\left[\mathrm{CO}_{2}\right]+$ elevated $\left[\mathrm{O}_{3}\right]$ treatments, showing that the negative effect of ozone was offset by the positive effect of $\mathrm{CO}_{2}$. The authors also found small changes in litter chemistry caused by elevated $\mathrm{O}_{3}$ combined with carbon dioxide, which influenced litter production rates and had potential to significantly alter stand-level chemical inputs to soil.

In disturbed areas, the composition of litter fall may have a great importance in the understanding of ecological properties, since the diversity of plant species is related to biomass production, availability of nutrients to the soil, and provide information about the relationships between living beings and the ecosystem. This work reported higher production of leaves among the litter fractions, followed by twigs, reproductive parts and miscellaneous. These results are consistent with the pattern observed for tropical forests (BARBOSA; FARIA, 2006; OSTERTAG et al., 2008, PAULA et al., 2009; ABREU et al., 2010; SOUSA-NETO et al., 2011, DICKOW et al., 2012). The specific separation of leaf fraction is of great importance as it can provide data on phenology, nutrition and patterns of nutrient cycling system (MORAES; DOMINGOS, 1997). According to Vitousek (1984), secondary forests have a higher turnover of leaves than primary forests, which might be an adaptation for restructuring the ecosystem.

The highest production of reproductive parts during the period with highest precipitation could be related to the increased investment of plants in reproduction, since the environmental conditions are less limiting. Barlow et al (2007) found higher production of fruits during the wet season in a secondary forest in Amazon. Sanches et al. (2009) examined data indicating that the fraction of reproductive parts (in their study corresponding to flowers) was observed only in the rainy season. However, some authors have found opposite results (CALDEIRA et al., 2008; PAULA et al., 2009). This fraction of litter fall might be used in different strategies of management of forest ecosystems. An example is the fruit that composes the fraction of reproductive litter fall. A large fraction of fruit may indicate the relationship between large vertebrates and plant seed dispersal. Laurance et al., (1998) related "fruit + seeds" to edge effects and found an increased production of this fraction within a forest fragment, reflecting the production by zoochoric species. This is especially important in urban areas, where the biogeographical islands are more pronounced.

The multiple regression showed a strong influence of precipitation and radiation on litter fall production. These meteorological factors have a strong relationship with the photosynthetic process, since water and light are essential variables to occur carbon fixation. This reinforces the hypothesis that the increase in litter fall production may have been a strategy of the plant community as a whole to the renewal of the foliage. The sampling $(n)$ in this study was relatively high, which further ensures the validity of the test.

The material exposed to decomposition showed a significant decrease in the first month, which might be expected due to the great contribution of the organic matter to the total litter fall. Sousa-Neto et al. (2011) found similar time to decay $50 \%$ and $95 \%$ of the material in a tropical Atlantic forest in Ubatuba, north cost of São Paulo State; for $50 \%$ of the litter fall 150 days are needed and for $95 \%, 2.2$ years. In a study carried out in a secondary forest in Rio de Janeiro, Fernandes et al. (2006) found a decomposition rate of $0.00194 \mathrm{~g} \mathrm{~g}^{-1}$ day and time do decay $50 \%$ of the litter is 357 days. It is noted that the forested areas have a higher decomposition rate with higher decomposition constants (K) and lower half-live time, which might be beneficial for the establishment of restoration programs for degraded areas. Sayer et al. (2007) showed that in a tropical forest of Panamá, Central America, a chronic increase in litter fall induced a substantial release of soil carbon in the medium term, due to decomposition. The authors concluded that an increased aboveground litter production in response to global climate change may convert considerable amounts of soil carbon to atmospheric carbon dioxide. It is important to consider that soil nutrient fluxes may change under different litter fall inputs and it could greatly affect soil fertility in a scenario of global change. Xu et al. (2013) showed that total $\mathrm{N}$ and $\mathrm{C}: \mathrm{N}$ ratios in the mineral soil increased with increased litter fall inputs. Homeier et al. (2012) found moderate nutrient inputs in a tropical montane forest in southern Ecuador. The authors suggested that whether this trend carries on, these parts of tropical

Revista Árvore, Viçosa-MG, v.38, n.4, p.591-600, 2014 
forest may have an increase in total $\mathrm{N}$ and $\mathrm{P}$ inputs with consequence in higher aboveground biomass and taller trees in this ecosystem.

According to Röderstain et al. (2005) at higher elevation it is possible that temperature decreases, affecting decomposition and thus lowers nutrient availability. The authors showed that trees respond to it by producing foliage with a higher degree of sclerophylly and by maintaining larger fine root systems. Martius et al. (2004) found that higher temperatures and lower soil moisture in younger forests under a developing canopy may contribute to slower decomposition rates, which reinforces the hypothesis of higher soil moisture and higher decomposition rate found in this study during the time of litterbag exposition.

\section{CONCLUSION}

Litter fall plays an important role in the nutrient cycling in this fragment of secondary forest and have a seasonal production of this material, being more effective during the wet season (September to March). Leaves showed the major contribution to total litter fall, as found by many authors in tropical forests. Reproductive parts showed an interesting peak during the wet season, which could mean a higher investment of plant community in reproduction due to a higher water availability. Precipitation and radiation presented a strong influence in the litter fall, which could be a strategy of the community for foliage renewal. Decomposition rates were strongly affected by rainfall during the summer time which may be driven by higher activity of decomposers in high temperatures. Thus, it is suggested future interannual investigation to confirm if there is a pattern in this seasonal result.

\section{ACKNOWLEDGMENTS}

We would like to thank the University Nove de Julho for providing a scholarship (FAPIC) for the second author and for supporting the material bought in this project. We also thank the two anonymous referees for the important suggestions.

\section{REFERENCES}

ABREU, J. R. S. P.; OLIVEIRA, R. R.; MONTEZUMA, R. C. M. Dinâmica da serapilheira em um trecho de floresta atlântica secundária em área urbana do Rio de Janeiro. Pesquisas Botânicas, n.61, p.279-291, 2010.
APRO, P. H. et al. Avaliação dos parâmetros de crescimento em plantas jovens de Phaseolus vulgaris L. (Feijão) expostas à poluição aérea da cidade de São Paulo. Exacta, v.10, n.1, p.92100, 2012.

BARBOSA, J. H. C.; FARIA, S. M. Aporte de serrapilheira ao solo em estágios sucessionais florestais na reserva biológica de Poço das Antas, Rio de Janeiro, Brasil. Rodriguésia, v.57, n.3, p.461-476, 2006.

BARLOW, J. et al. Litter fall and decomposition in primary, secondary and plantation forests in the Brazilian Amazon. Forest Ecology and Management, v.247, n.1, p.91-97, 2007.

CALDEIRA, M. V. W. et al. Quantificação de serapilheira e de nutrientes em uma Floresta Ombrófila Densa. Semina: Ciências Agrárias, v.29, n.1, p.53-68, 2008.

CHAVE, J. et al. Regional and seasonal patterns of litter fall in tropical South America, Biogeosciences, v.7, p.43-55, 2010.

DENT, D. R. et al. Nutrient fluxes via litter fall and leaf litter decomposition vary across a gradient of soil nutrient supply in a lowland tropical rain forest. Plant Soil, v.288, p.197215, 2006.

DICKOW, K. M. C. et al. Produção de serapilheira em diferentes fases sucessionais de uma floresta subtropical secundária, em Antonina, PR. Cerne, v.18, n.1, p.75-86, 2012.

FACELLI, J. M.; PICKETT, S. T. A. Plant litter: its dynamics and effects on plant community structure. The Botanical Review, v.57, p.132, 1991.

FERNANDES, M. M. et al. Aporte e decomposição de serapilheira em áreas de floresta secundária, plantio de sabiá (Mimosa caesalpiniaefolia Benth.) e andiroba (Carapa guianensis aubl.) na Flona Mário Xavier, RJ. Ciência Florestal, v.16, n.2, p.163-175, 2006.

FERREIRA, M. L.; DOMINGOS, M. Seasonal characterization of antioxidant responses in plants of Ipomoea nil cv. Scarlet O'Hara. Brazilian Journal of Biology, v.72, n.4, p.831-837, 2012. 
FERREIRA, M. L. et al. Critical analysis of the potential of Ipomoea nil 'Scarlet O'Hara' for ozone biomonitoring in the sub-tropics.

Journal of Environmental

Monitoring, v.14, p.1959-1967, 2012.

FIGUEIREDO FILHO, A. et al. Avaliação estacional da deposição de serapilheira em uma Floresta Ombrófila mista localizada no Sul do estado do Paraná. Ciência Florestal, v.13, n.1, p.11-18, 2003.

KURUPPUARACHCHI, K. A. J. M.; SENEVIRATNE, G. Predicting aboveground biomass increment of tropical forests from litterfall. Ceylon Journal of Science, v.42, n.1, p.35-40, 2013.

HOMEIER J. et al. Tropical andean forests are highly susceptible to nutrient inputs - rapid effects of experimental $\mathrm{n}$ and $\mathrm{p}$ addition to an ecuadorian montane forest. PLoS ONE v.7, n.10, 2012: e47128. doi:10.1371/ journal.pone.0047128

LAURANCE, W. F. et al. Rain forest fragmentation and the dynamics of Amazonian tree communities. Ecology, v.79, p.2032-2040, 1998.

LEITÃO-FILHO, H. F. Considerações sobre a florística de florestas tropicais e sub-tropicais do Brasil. IPEF, v.35, p.41-46, 1987.

LIEBERG, S. A. Análise sucessional de fragmentos florestais urbanos e delimitações de trilhas como instrumento de gestão e manejo no programa de uso público do Parque Ecológico do Guarapiranga, São Paulo. 2003. 100 f. Tese (Doutorado em Biologia vegetal) Universidade Estadual de São Paulo, 2003.

LIU, L. et al. Effects of elevated concentrations of atmospheric $\mathrm{CO} 2$ and tropospheric $\mathrm{O} 3$ on leaf litter production and chemistry in trembling aspen and paper birch communities. Tree

Physiology, v.25, p.1511-1522, 2005.

LOPES, M. I. S. et al. Ciclagem de nutrientes minerais. In: SYSLVESTRE, L. S.; ROSA, M. M. T. Manual metodológico para estudos botânicos na Mata Atlântica. Seropédica: EDUR - UFRRJ, 2002. p.72-102.

MALHADO, A. C. M. et al. Seasonal leaf dynamics in an Amazonian tropical forest. Forest Ecology Manage, v.258, p.1161-1165, 2009.
MARTIUS, C. et al. Litter fall, litter stocks and decomposition rates in rainforest and agroforestry sites in central Amazonia. Nutrient Cycling in Agroecosystems, v.68, p.137-154, 2004.

MAYER, R. Interaction of forest canopies with atmospheric constituints: aluminium and heavy metals. In: ULRICH, B.; PANKRATH, J. (Ed.)

Effects of accumulation of air pollutants in forest ecosystems. Dordrecht: D. Reidel, 1983. p.47-55.

MORAES, R. M.; DOMINGOS, M. Elementos minerais em folhas de espécies arbóreas de Mata Atlântica e Mata de Restinga, na Ilha do Cardoso, SP, Revista Brasileira de Botânica, v.20, n.2, p.133-138, 1997.

OLIVEIRA, R. R.. O rastro do homem na floresta: sustentabilidade e funcionalidade da Floresta Atlântica sob manejo caiçara. 1999. $148 f$. Tese (Doutorado em Geografia) - Universidade Federal do Rio de Janeiro, Rio de Janeiro, 1999.

OSTERTAG, R. et al. Litter fall and decomposition in relation to soil carbon pools along a secondary forest chronosequence in Puerto Rico.

Ecosystems, v.11, n.5, p.701-714, 2008.

PAULA, R. R. et al. Aporte de nutrientes e decomposição da serapilheira em três fragmentos florestais periodicamente inundados na ilha da Marambaia, R.J. Ciência Florestal, v.19, n.2, p.139-148, 2009.

PEREIRA, M. G. et al. Aporte e decomposição da serapilheira na Floresta Atlântica, Ilha da Marambaia, Mangaratiba, RJ. Ciência Florestal, v.18, n.4, p.443-454, 2008.

POGGIANI, F. Alterações dos ciclos biogeoquímicos em florestas. Revista do Instituto Florestal, v.4, p.734-739, 1982.

REZENDE, C. P. et al. Litter deposition and disappearance in Brachiaria pastures in Atlantic forest region of South Bahia, Brazil. Nutrient Cycling in Agroecosystems, v.54, n.1, p.99-112, 1999.

RÖDERSTEIN, M. et al. Above- and below-ground litter production in three tropical montane forests in southern Ecuador, Journal of Tropical Ecology, v.21, p.483-492, 2005.

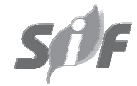

Revista Árvore, Viçosa-MG, v.38, n.4, p.591-600, 2014 
SANCHES, L. et al. Dinâmica sazonal da produção e decomposição de serrapilheira em floresta tropical de transição. Revista Brasileira de Engenharia Agrícola e Ambiental, v.13, n.2, p.183-189, 2009.

SAMPAIO, F. A. R. et al. Balanço de nutrientes e da fitomassa em um Argissolo Amarelo sob floresta tropical amazônica após a queima e cultivo com arroz. Revista Brasileira de Ciências do Solo, v.27, n.6, p.161-1170, 2003.

SAYER, E. J. et al. Increased litter fall in tropical forests boosts the transfer of soil $\mathrm{CO}_{2}$ to the Atmosphere. PLoSONE, v.2, n.12: e1299. doi:10.1371/journal.pone.0001299, 2007.

SILVA, R. M. et al. Influência de variáveis meteorológicas na produção de liteira na Estação Científica Ferreira Penna, Caxiuanã, Pará. Acta Amazonica, v.39, p.573-582, 2009.

\section{SOS MATA ATLÂNTICA. Relatórios e} balanços. Acesso ao relatório de vizibilidade da SOS Mata Atlântica. Disponível em: http:// www.sosma.org.br/quem-somos/relatorios-ebalancos acesso em 30 de ago. de 2013.

SOUSA-NETO, E. et al. A. Soil-atmosphere exchange of nitrous oxide, methane and carbon dioxide in a gradient of elevation in the coastal Brazilian Atlantic forest. Biogeosciences, v.8, p.733-742, 2011.

TOLEDO, L. O.; PEREIRA, M. G. Dinâmica da deposição de serapilheira: um estudo prolongado em florestas secundárias em área de mata Atlântica. Floresta e Ambiente, v.11, n.1, p.39, 2004.
VIDAL, M. M. et al. Produção de serapilheira em floresta Atlântica secundária numa paisagem fragmentada (Ibiúna, SP): Importância da borda e tamanho dos fragmentos. Revista Brasileira Botânica, v.30, n.3, p.521-532, 2007.

VITAL, A. R. T. et al. Produção de serapilheira e cliclagem de nutrientes de uma floresta estacional semidecidual em zona primaria. Revista Árvore, v.28, n.6, p.793-800, 2004.

VIBRANS, A. C.; SEVEGNANI, L. Decomposição de nutrientes através da queda da liteira em dois remanescentes de Floresta Ombrófila Densa em Blumenau - SC. Revista de Estudos Ambientais, v.2, n.1, p.41-55, 2000.

VITOUSEK, P. M. Litter fall, nutrient cycling, and nutrient limitation in tropical forests. Ecology, v.65, p.285-298, 1984.

XU, S. et al. Variability of aboveground litter inputs alters soil physicochemical and biological processes: A meta-analysis of litter fallmanipulation experiments. Biogeosciences Discussion, v.10, p.5245-5272, 2013.

WERNECK, M. S. et al. Produção de serapilheira em trechos de uma floresta semidecídua com diferentes graus de perturbação na Estação Ecológica do Tripuí, Ouro Preto, MG. Revista Brasileira de Botânica, v.24, n.2, p.195-198. 2001.

YONG, C. E. F. Causas socioeconômicas do desmatamento da Mata Atlântica brasileira. In: GALINDO-LEAL, C.; CÂMARA, I. G. (Org.) Mata Atlântica: biodiversidade, ameaças e perspectivas. Belo Horizonte: IDM Composição e Arte, 2005. p.103-118. 